\title{
Destruction of Communicative Pragmatics in Contemporary Absurdist Dramaturgic Texts
}

\section{Деструкція комунікативної прагматики в сучасних абсурдистських драматургійних текстах}

\author{
Valeria Koroliova \\ Dr. in Philology, \\ Assistant Professor
}

\author{
Валерія Корольова \\ доктор філологічних наук, \\ доцент
}

E-mail: koroliova@i.ua

https://orcid.org/0000-0002-7482-0517

Iryna Popova

Dr. in Philology,

Professor

\section{Ірина Попова}

доктор філологічних наук, професор

E-mail: dekanat fuifm@i.ua

https://orcid.org/0000-0003-1423-2358

Oles Honchar Dnipro

National University

72, Haharin Ave., Dnipro,

Ukraine, 49010
Дніпровський національний університет імені Олеся Гончара $\checkmark$ просп. Гагаріна, 72, Дніпро,

Україна, 49010

Original manuscript received September 20, 2019

Revised manuscript accepted March 23, 2020

\begin{abstract}
The aim of the article is characteristics of mechanisms of pragmatics distraction in communication of active participants of modern Ukrainian plays with features of the theatre of the absurdity. Structural and contextual mechanisms of dialogic speech depragmatization are singled out on factual material. In a dramatic dialogue absurdity is explained as a purposeful instruction to convey the thought about illogicalness and chaotic nature of reality, the aimlessness of a human being.

The main methods of the study are descriptive, context-interpreting and presuppositional.
\end{abstract}

ISSN 2309-1797 (print) / 2415-3397 (online) 
Study results. One of absurdity occurrence mechanisms is depragmatization purposeful non-normative usage of language pragmatic resources. We identify structural and contextual violations within depragmatization. Structural violations are characteristic for an absurdist drama in which characters' cues do not have illocutionary and thematic coherence. Another type of structural violations is conscious violations of formal structure of linguistic units. Role exchange, during which an active participant takes over someone else's communicative role, is an example of contextual depragmatization. Within contextual violations we also identify the group of cognitive violations which is based on non-observance of causally consecutive and logical connections. Anomalies based on an arbitrary choice of language stylistic means, which are uncoordinated with general principles of stylistic formalization of the text, are considered the contextual variety of depragmatization.

Conclusions. Structural and contextual communicative violations are used by playwrights to activate the sense of the situational absurdity depicted in a work. Active participants of drama of the absurdity communicate without communicative purpose and taking into account situational needs, which results in actualization of pragmatic potential of used linguistic units, falsification of meaningful speech.

Key words: pragmatics, dramaturgical discourse, linguistic absurdity, depragmatization, structural and contextual violations, «non-referential» statements.

\section{Вступ}

Новітня лінгвістика тексту інтегрує антропозорієнтовані лінгвістичні парадигми для міждисциплінарного дослідження художнього тексту, що стає найважливішим джерелом когнітивних i дискурсивних знань про людину, яка створює та сприймає цей текст. Як слушно зауважує С. Реферовська, художній текст вивчають як маніфестацію мовленнєвої діяльності, що врегульовано певними мовними законами (Реферовская, 2007). I літературний текст, у якому навмисно порушено ці закони, викликає потрійний інтерес до вивчення і в літературознавців, і в психологів, і в лінгвістів.

Низку всесвітньо відомих п’єс ХX ст. («Лиса співачка», «Носороги», «Стільці» Е. Йонеско; «Очікуючи Годо», «Щасливі дні» С. Беккета; «Балкон», «Служниці» Ж. Жене) характеризують як абсурдні (Попов, 2001). Однією з ознак цих драматичних творів критики вважають «безглуздий діалог», що загалом не можна трактувати в межах цілісного дискурсу, виводити на комунікативний рівень через відсутність прагматичної основи. 
Важливою передумовою в поясненні мовного абсурду стають психолінгвістичні наукові розвідки, у яких абсурд обгрунтовують через опозицію «значення - смисл» (Леонтьев, 2003), «безглузде осмислене» (Гамалей, 2001). Саме остання дихотомія $\epsilon$ значущою для виявлення механізмів виникнення абсурду в драматичних текстах.

Незважаючи на досить тривалу історію свого вивчення, драма абсурду викликає зацікавлення дослідників і сьогодні (Бацевич, 2012; Ведмедєв, 2018; Гаращенко, 2012; Коляса, 2016; Кравченко, 2010; Лукьянова, 2002; Мукан, 2015; Rehman \& Larik, 2017 та ін.). Сучасні науковці в межах лінгвістичного аспекту окреслюють основні напрями усвідомлення людиною абсурдності власного існування, зокрема через порушення мовної структури п’єс (Бернар, 2013), порівнюють комічність і драматичність мовної реалізації абсурду (Azizmohammadi \& Kohzadi, 2011), акцентують увагу на позавербальних засобах репрезентації «філософії абсурду» (Миропольська, 2019), наголошують на «акомунікабельності» мови драматичного твору (Реутова, 2014). Утім, у цих наукових розвідках не вирішено остаточно проблему прагматичної мети діалогічного спілкування в абсурдистських п'єсах, не визначено механізми створення абсурдності комунікативної ситуації.

Враховуючи широкий спектр аналізу «феномену абсурдності», вважаємо за потрібне наголосити на важливості висвітлення цих питань. Актуальність такого дослідження пояснюємо зростанням інтересу до явища абсурду в періоди культурно-історичних трансформацій, властивих Україні XXI ст. Джерелом аналізу обрано твори, у яких наявні фрагментарні або фундаментальні ознаки абсурдистського театру, зокрема «Розібрати М.*** на запчастини» В. Сердюка, «Двадцять такий-то з'їзд нашої партії» В. Діброви, «Маринований аристократ» І. Коваль, «На виступцях» К. Демчук, «Я. Сipiyc. Кентавр» Л. Паріс, «Різниця» А. Вишневського, «Лізикава» В. Кожелянка й В. Сердюка та ін.

Метою статті $€$ характеристика механізмів руйнації прагматики в спілкуванні дійових осіб сучасних українських п’єс, маркованих ознаками абсурдистського театру. Поставлена мета передбачає виконання таких завдань: визначити основні різновиди комунікативних порушень, що зумовлюють появу абсурду; класифікувати наявні механізми депрагматизації 
комунікації персонажів; 3'ясувати причини використання автором цих механізмів.

\section{Методи та методики дослідження}

Досягнення окресленої мети зумовлює використання комплексного підходу для пояснення прагматичних функцій мовних фактів. Основними методами, застосованими під час дослідження, постають контекстуально-інтерпретаційний, пресупозиційний, концептуальний й дистрибутивний аналіз, а також метод опитування. У науковій розвідці використано загальнофілософські методи спостереження, аналізу, синтезу, порівняння, узагальнення, абстрагування мовних і мовленнєвих явищ у їхній динаміці, а також універсальний метод лінгвістичних студіювань - описовий.

\section{Результати та дискусії}

У драмі прагматична значущість мовних одиниць посилена через родову специфіку, до того ж кожна мовленнєва дія має подвійне спрямування - це водночас і засіб комунікації між персонажами, i засіб впливу автора на реципієнта (читача). $\mathrm{y}$ межах нашого дослідження актуальним $\epsilon$ саме комунікація автора із читачем через посередництво дійових осіб - внутрішніх комунікантів п’єсі. Важливим у цьому разі постають і соціальні, i власне лінгвістичні норми використання мови, за якими стоїть постійний вибір, усвідомлений або неусвідомлюваний, зумовлений зовнішніми чи внутрішніми мовними чинниками (Verschueren, 1999). Драма абсурду виражає світ як абсурд, відбиває песимізм, некомунікабельність, відчуття безглуздості людського життя через алогічність дій, зокрема й комунікативних. Отже, художній потенціал абсурду виявляємо через його комунікативні функції. 3 одного боку, ці функції активно заперечують дослідники, 3 іншого - лінгвісти стверджують, що абсурдність у комунікації породжує інтенційні абсурдні комунікативні смисли естетичного характеру. Погоджуючись 3 останньою теорією, зауважимо, що людина здебільшого свідомо обирає мовні засоби для певної комунікативної потреби. Висловлення, за слушною думкою С. Шабат-Савки (2018), - це засіб вербалізації інтенції, що має 
афективний та інтелектуальний складники. Отже, за будь-якою фразою, навіть абсурдною, стоїть певний комунікативний намір.

У драматургійному діалозі, що вербалізує мовленнєву діяльність автора для опосередкованого впливу на потенційного читача, абсурдність спричинена цільовою настановою на донесення до читача думки про алогічність та хаотичність довколишнього світу, безцільність людського буття.

Серед основних причин появи комунікативного абсурду науковці називають порушення постулатів, що визначають зв'язок реальної дійсності з дійсністю, вербалізованою актом мовлення. Це постулати детермінізму, наявності загальної пам'яті, прогнозування майбутнього, тотожності, інформативності, семантичної зв'язності й істинності (Ревзина \& Ревзин, 1971). Як зазначають дослідники, такі комунікативні дисфункції найчастіше характеризують осіб 3 неврологічними розладами, які істотно впливають на соціальну взаємодію (Volden, Mulcahy \& Holdgrafer, 1997).

С. Івлєва розмежовує за чинниками творення семантичний, синтаксичний та прагматичний комічний абсурд, виокремлюючи в останньому логічний та оцінний різновиди (Ивлева, 2010).

На думку О. Кравченко (2010), мовний абсурд постає через спрямоване ненормативне використання семантичних, прагматичних та синтаксичних засобів мови. Механізмами породження абсурду в мові $\epsilon$ десемантизація, депрагматизація та деструктуризація. Десемантизація пов'язана 3 порушенням семантичних норм мови. Деструктуризація виникає під час порушення когезії й / або когерентності тексту, а депрагматизація зумовлена ненормативним використанням прагматичних ресурсів.

Зупинимося докладніше на механізмах виникнення абсурду, серед яких з урахуванням дослідженого матеріалу виокремлюємо структурну та контекстуальну депрагматизацію як найхарактернішу для абсурдистської драматургії в сучасній Україні.

Структурна депрагматизація виявляє руйнацію зовнішньої структури комунікації й зумовлена переважно недотриманням принципу кооперації Г. Грайса, за яким спілкування має розвиватися за моделлю згоди, де кожен учасник керується правилом:

«твій комунікативний внесок на певному крочі діалогу має бути таким, якого потребує спільна мета й спрямування цьього діалогу» (Грайс, 1985: 222). 
Комунікативні ситуації з порушенням зазначеного принципу $\epsilon$ досить характерними для абсурдистської драми, у якій репліки персонажів не мають іллокутивної й тематичної зв'язності, напр.:

Краля Чирва. Скоро вихід нашого божевільного Короля.

Краля Жир. Хто знає, щз йому спаде на думку.

Чужий Жир. Запалили всі свічки.

Краля Вино. Минулого разу він наказав скарати гостя.

Чужий Жир. Сі черепки... Вони хвилюють.

Краля Чирва. Бідний гість. Він до останньої хвилини не міг повірити, що се насправжки.

Чужий Жир. Так-так, хвилюють. Се точне слово («На виступцях» К. Демчук).

Наведений уривок демонструє полілогічне «розшарування» на два рівні: кооперативне спілкування Кралі Жир, Кралі Вино й Кралі Чирви та комунікативну партію персонажа Чужий Жир, репліки якого суперечать темі розмови інших комунікантів і порушують зв'язність комунікативних ходів дійових осіб. Різноспрямовані репліки, не виконуючи максиму відношення («Не відхиляйся від теми»), спричинюють появу абсурду в спілкуванні. Такі приклади свідчать про фундаментальну втрату орієнтації, розірваність між зовнішнім i внутрішнім світом комунікантів. Це підтверджує концепцію щодо новітньої глобальної втрати суспільного зацікавлення діалогом, що поширено останнім часом у мовознавстві (Лазуткина, 2013).

Найяскравіше реверсивність реплік персонажів 3 порушенням зовнішньої комунікативної структури відбита в драматургійних дилогах (спілкуванні двох осіб). У цьому разі порушено прагматику спілкування як життєво необхідної кооперативної активності між людьми, у якій значення кожного мовленнєвого акту сконструйовано всіма учасниками комунікації (Bara, 2010), напр.:

Чоловік. (1) А де мені ще сховатись, як не в ию газету? Де? (кричить). Де? Де? Де? (б’є кулаком об бильие крісла).

Жінка (бере люстерко, довго себе розглядас). Ось ще одна зморшка. Тепер їх рівно шістнадиять під обома очима, якщо ще додати дві біля губів, шість на чолі. (2) Скільки це буде разом? Чоловік. Воно тупе, Воно арифметики не вчиться, Воно хоче лите гратись.

Жінка. Тоненькі такі зморики, немовби хтось ножем прорізав.. Я не хочу старіти. 
Чоловік (шелестить газетою). Послухай. Що в світі коїться. Якийсь чоловік убив всю свою родину і навіть гостей. Цікаво... Жінка. (3) А що зробив ти?

Чоловік (шелестить газетою). В Тирасполі завідувачем міської бібліотеки праџюе бабуся, яка під час останньої війни вбила дванадиять чоловіків. Вона дає інтерв'ю $і$ зізнається, що іï тягне до хлопчиків. Здуріла. (4) Як ти думаєш?

Жінка. Я не хочу старіти... («Лізикава» В. Кожелянко, В. Сердюк).

У поданому уривкові цифрами позначено ймовірні початки комунікативних епізодів, ініційовані комунікативними лідерами (Чоловіком, Жінкою). Відсутність реакції на стимульні репліки пояснює руйнування структури діалогічної взаємодії внаслідок суперечності між мікротемами комунікативної партії Чоловіка (пошук схованки, газетні новини) та Жінки (проблема старіння, претензії до чоловіка), що порушує умови успішної комунікації. У цій ситуації комунікативну партію Жінки можна зарахувати до озвучених реплік віртуальної мовної особистості, оскільки ऑї висловлення, власне, не перетинаються з партією Чоловіка як реальної мовної особистості та схожі на «невербалізовану» мовленнєву діяльність людини із психічними порушеннями (Шпильная, 2019).

До структурної депрагматизації зараховуємо також свідомі порушення формальної структури мовних одиниць. Аномалії у формальній структурі здебільшого пов'язані зі зміною графічної або орфографічної форм слова, що впливає на комунікативну результативність, напр.:

Ц. Це таке знання особисте, Дора. Не все пам'ятаю, але щзось таке казав по телезбоченню один лікар-психоганалітикпромовець у приватному передвиборчому диспуті з учнями пердовиків сільського госпоздирства! («Я. Сіріус. Кентавр» Л. Паріс).

До цього різновиду депрагматизації належать висловлення 3 порушенням формальної зв'язності тексту через свідоме авторське недотримання синтаксичних мовних норм, напр.:

Ц. ...зрю зірку злидар зулу зілля зле назустріч зузу злу зірвати змій зима зілляти зжати злість зулу о Зитмунд звіддалік зловити ззаду («Я. Сіріус. Кентавр» Л. Паріс). 
Відсутність когезії в наведеній репліці позбавляє іiі здатності передавати цілісний зміст, засвідчує відсутність думки в мовця, занурюючи читача до світу абсурду, у якому людина дисгармонує 3 іншими людьми й собою.

Другим актуальним різновидом деструкції комунікативної прагматики $є$ контекстуальна депрагматизація, зумовлена порушенням фізичного (фактичне комунікативне середовище), когнітивного (спільні пресупозиції учасників комунікації), особистісного (соціальні відносини комунікантів) контекстів спілкування.

До механізмів контекстуальної депрагматизації з порушенням фізичного контексту зараховуємо обмін ролями, за якого дійова особа бере на себе іншу роль, що водночас не викликає жодної реакції в інших героїв. Схожу ситуацію спостерігаємо в п’єсі «Маринований аристократ» I. Коваль, де актор Борис, який емігрував до Англії й працює прислугою у старої подружньої пари, постає в ролі то жінки, то собаки, то незнайомця. Наприклад:

Актор. Де я зупинився? Ага, я дійшов висновку, що ми переживаємо найпринизливіший період в історї собаитвв: «принеси газету», «принеси капиіi», «сиди», «стій». Цей культ трудоголиків став ідеєю фікс нашого буття.

Стара. Дай лапу. (Пауза.) Вінстоне. Лапу. (Дає руку.) Дай другу. (Пауза. Дає ногу і ніби твалтує Стару.) Пустунчику.

Актор. Нарешті! Відтепер даватиму лапу тільки з власного бажання. (Потягується. Позіхає.) На чому я спинився? Ага. Що більше ми - собаки - працюємо, то менший апетит до розкішного життя...

Стара. (Затуляе носа.) Гадаю, Вінстона треба скупати.

Актор. Грр-грр... ні в якому разі... (Стоячи навколішки, підняв угору руки-лапи.) Будь ласка. Хоч сухарика («Маринований аристократ» I. Коваль).

Обмін ролями є очевидним для читача драми, який усвідомлює ознаки іманентної ситуації комунікативного абсурду. Адже прийнятний у комунікативному аспекті діалог персонажів ілюструє контекстуальні порушення, зокрема спілкування із твариною як активним комунікантом. Утім, здатність собаки спілкуватися 3 людиною не є «пусковим механізмом» абсурдизації, що, швидше, зумовлена відсутністю здивування в людини (Cmapoï), яка 
розмовляє із твариною. Ця ситуація ілюструє тезу щодо вагомості ролі міжсуб'єктної взаємодії в забезпеченні умов для створення соціальних суджень і спрощення висновків, зокрема для читача (Mihael \& Overgaard, 2012).

Окремо виділяємо групу порушень когнітивного контексту, що грунтуються на недотриманні причиново-наслідкових і логічних зв'язків. Абсурд - це семантична категорія, відповідна не мовному значенню, а смислу. Статичні мовні значення не спроможні передавати абсурд, характерний лише для дискурсу в умовах динамічного смислового потенціалу. Прикладами прагмакогнітивних порушень $є$ висловлення, що вербалізують ситуації, які суперечать базовим знанням об'єктивної дійсності. За визначенням О. Кравченко, такі фрази можна трактувати як «нереференційні», зміст яких суперечить реальності й усталеним нормам (Кравченко, 2010). Наприклад:

Жінка № 1. Облиш, ие вже з іншої опери! Заведи краще музику, дуже хочеться танцювати! Шкода, щио ніхто не вмер («Розібрати М.** на запчастини» В. Сердюк).

Зовнішньо висловлення не $\epsilon$ суперечливим, однак його можна зарахувати до суперечності. У таких прикладах фіксуємо кооперативне спілкування персонажів, нормативну зміну комунікативної ініціативи. Незважаючи на те, що спілкування відбувається за зразком розмовного діалогу й має комунікативний результат, текстовий абсурд постає як суперечність між змістовним складником i смислом актуалізованих у дискурсі позамовних когніцій реципієнтів цього тексту. Мовний абсурд фіксуємо внаслідок спотворення експлікації мовної картини світу, руйнації усталених образів. Наприклад:

Жінка № 2. (1) Послухай-но, чому на кухні немає холодильника? Ми б зробили зараз коктейлів, або морозива.

М. (2) Та ти ж забрала його разом з меблями...

Жінка № 2. (3) Я й забула. Тоді нічого, не звертай уваги. Можна, звичайно, зробити присутнім часникові клізми («Розібрати M.** на запчастини» В. Сердюк).

Комунікативно нормативна стимульна репліка Жінки № 2 (1) має адекватну реактивну репліку $M$. (2), що водночас спричинює абсурдну щодо першої стимульної репліки реакцію Жінки № 2 (3). 
Унаслідок маємо в драмі алогічний вибір пригощань для гостей коктейлі або часникові клізми. У цьому разі комунікативно неконфліктний діалог ілюструє відсутність здійснення істинної референції, що спрямовує читача на висновок про абсурдність спілкування. У читача така комунікація викликає конфлікт між власними пресупозитивними знаннями й експліцитною інформацією, отриманою $з$ тексту. Водночас, на думку В. Звєгінцева, побудований над «прагматичною порожнечею» діалог має граматично правильну форму, яка власне перебирає на себе прагматичні функції й заміщує осмислене мовлення (Звегинцев, 1973).

«Нереференційними» постають подекуди й паратекстові елементи драми абсурду, зокрема заголовки. Актуалізуючи сильну позицію назви твору, автори здебільшого конденсують у ньому тему й ідею п'єси, посилюючи прагматичний потенціал драматургійного заголовка. Утім, подекуди письменники не використовують цього потенціалу заголовка й реалізують у ньому лише комунікативну стратегію інтригування читача. Прикладом $\epsilon$ назва п’єси «Лізикава» В. Кожелянка й В. Сердюка, яку під час прочитання нерідко фіксуємо в тексті щоразу з новим асоціативним значенням. Для виявлення прагматичного потенціалу зазначеної назви проведено опитування, у якому респонденти (студенти й викладачі Дніпровського національного університету імені Олеся Гончара - 85 осіб) мали до прочитання п’єси дати відповідь на запитання «Що, на Вашу думку, означає ця назва?» Варіативність відповідей була розгалуженою, найчастотнішими зафіксовано такі тлумачення: «дивне ім'я героїні», «лізе кава», «назва місця подій», «щось агресивне», «назва хвороби», «назва спортивної гри», «не знаю», «кава, що належить Лізі», «щось, пов’язане 3 харчуванням», «нісенітниця». Насправді назву п’єси вживають у репліках персонажів відокремлено від теми діалогу, до того ж зміст неологізму постійно змінюється. Отже, читач отримує щоразу нову інтерпретацію значення заголовка:

Жінка. Як боявся? Як Лізикави? До речі. Що це означає по-японськи? Чоловік. Так боявся. Нічого че не означає. I не по-японськи ие; Жінка. Хто ие тобі сказав? Лізикава?; Чоловік. Дітей треба розважати так: «Лізе кава», казати $i$ перебирати пальиями по його пухкенькому черевию, а воно так весело сміється, $і$ коли воно найрадісніме сміється, треба 
боляче вдарити пальияли по його прозорих очицях, але так аби не осліпло; Чоловік. Полічуія - цее Лізикава? («Лізикава» В. Кожелянко, В. Сердюк).

Після прочитання драми респонденти дали відповідь на запитання «Чи правильним було Ваше тлумачення?» і «Як Ви зараз розумієте заголовок?» Зауважимо, що 100\% опитаних визнали, що помилилися в гіпотезі щодо значення назви, а 87,0\% респондентів зазначили, що не зрозуміли назву й після прочитання твору. Отже, сприйняття тексту не лише не підтвердило жодну із запропонованих читацьких гіпотез, а й, власне, не дало пояснення неологічній назві твору, залишаючи читача в стані напруження й невизначеності. Така ситуація спричинена словесним нонсенсом, що $\epsilon$ ознакою драми абсурду. Водночас це порушує загальне спрямування художнього твору (з урахуванням його неоднозначності та багатомірності інформації в ньому) на категорію «розуміння» в комунікації «автор» - «читач» (Сапрыгина, 2012).

Останнім різновидом контекстуальної депрагматизації $\epsilon$ порушення особистісного контексту, характеризовані меншим потенціалом порівняно 3 першими двома типами й грунтуються на довільному виборі стилістичних засобів мови, неузгоджених i3 загальними принципами стилістичного оформлення тексту й антагоністичних у певний спосіб до змальовуваної комунікативної ситуації драматургійного твору. Наприклад, у п’єсі В. Діброви «Двадцять такий-то з'іззд нашої партії» спілкування високоповажаних політичних діячів раптово набуває фамільярного характеру із залученням жаргонної лексики:

Родіна. Bсе харе!

Товариш Харашо. Ти мари мені!

Вофіс. Фуфла не держимо.

Товариш Харашо. Шукасу!

Далдов (до Товариша Харашо). Лана ти! Крути бадягу!

Товариш Харашо (до Всіх членів президіi). Манал я вашу бадягу! («Двадцять такий-то з’ізд нашої партії» В. Діброва).

На думку П. Сімпсона, таке спілкування варто зарахувати до «дивного мовлення» («odd talk»), за якого зразки одного дискурсивного контексту перенесені й використані в іншому контексті, де їх не мало б бути (Simpson, 1998). 
«Дивним мовленням» можна вважати й комунікативну діяльність героя п’єси А. Вишневського «Різниця» Дальтоника, який наводить розлогі наукові коментарі, вставляючи у свої репліки докладні тлумачення слів, суперечливі й невиправдані в побутовому спілкуванні, наприклад:

Різниия (наступає). Ви щчо натякаєте, щчо ие я - худоба?

Зелений і Коричневий. Ні-ні.. Ви щзо? I не думали...

Дальтоник. Худоба... Худоба - поняття досить містке $i$ багатозначне. Але в основному виділяють два види. Перший велика рогата худоба. Досить загрозлива на вигляд. Харчується в основному зеленню у значних кількостях, - тому майже постійно щось пережовує. Де прив'яжуть - там і пасеться. Як правило, час від часу потребує зміни пасовища, доки на старому не виросте нова зелень («Різниця» А. Вишневський).

Схожі порушення драматурги використовують для активізації почуття абсурдності ситуації, змальованої в творі, для наголошення на одночасній наявності реального й фантастичного, високого й ницого, патетичного й фарсового.

\section{Висновки}

Отже, основними механізмами експлікації прагматичного порушення комунікації в спілкуванні персонажів сучасних абсурдистських українських п’єс є структурна та контекстуальна депрагматизація. Структурна депрагматизація спрямована на зовнішню руйнацію комунікації, нівелювання ii змістовності та результативності. Контекстуальна депрагматизація за формальної правильності діалогів демонструє іманентний комунікативний абсурд, що виявлено через порівняння отримуваної інформації у спілкуванні дійових осіб із читацькими пресупозиціями, усвідомлюваною реальністю. Причини депрагматизації вбачаємо в авторській настанові на фіксацію в репліках персонажів абсурдності світу, алогічності людського життя, що передусім відбито в комунікативних порушеннях. Утім, прагматичну основу такої комунікації виявляємо в транспозиції до іншого рівня драматургійної комунікації - діалогу «автор - читач», у якому драматург використовує абсурдність спілкування персонажів як засіб впливу на потенційного реципієнта драматургійного тексту. 


\section{Література}

Бацевич, Ф.С. (2012). Абсурдний художній текст у вимірах лінгвістичної прагматики. Мовознавство, 1, 18-30.

Бернар, Б.Г. (2013). Тематична сітка англомовної драми абсурду. Філологічні трактати, 5 (2), 13-18.

Ведмедєв, В.М. (2018). Рецепція абсурдного у філософсько-антропологічному дискурсі. Автореф. дис. канд. філософ. наук. Київ.

Гамалей, Н.С. (2001). Психолингвистическое исследование категории «осмысленное - бессмысленное» как константы концептуальной системы индивида. Автореф. дисс. канд. филол. наук. Барнаул.

Гаращенко, Л. (2012). Поетика «Театру абсурду» в українській драматургії (на матеріалі п’єси I. Костецького «Спокуси не святого Антона»). Вісник Черкаського університету, 25, 81-97.

Грайс, Г.П. (1985). Логика и речевое общение. Е.В. Падучева (Ред.), Новое в зарубежной лингвистике. Лингвистическая прагматика (с. 217-237). Москва: Прогресс.

Звегинцев, В.А. (1973). Языл и лингвистическая теория. Москва: Издательство Моск. ун-та.

Ивлева, С.В. (2010). Лингвосемиотические характеристики комического абсурда. Автореф. дисс. канд. филол. наук. Волгоград.

Коляса, О.В. (2016). Сутність абсурду в постмодерністському художньому тексті. Молодий вчений, 3, 531-533.

Кравченко, О.В. (2010). Явления языкового абсурда в художественных текстах. Автореф. дисс. канд. филол. наук. Таганрог.

Лазуткина, Е.М. (2013). Речевая культура мегаполиса. Полифония большого города - 2 (с. 54-69). Москва: МИЛ.

Леонтьев, Д.А. (2003). Психология смысла. Природа, строение и динамика смысловой реальности. Москва: Смысл.

Лукьянова, В.С. (2002). Коммуникативные неудачи в комедии абсурда. Автореф. дисс. канд. филол. наук. Москва.

Миропольська, Є.В. (2019). Естетичні засади «філософії абсурду» в мистецьких практиках XX століття. Київ: Видавництво Ліра-К.

Мукан, В.С. (2015). Поетика абсурду в українській драматургії першої половини XX століття (на матеріалі творів Миколи Куліша та Ігоря Костецького). Автореф. дис. канд. філол. наук. Київ.

Попов, Ю. (2001). Драма абсурду. А. Волков (Ред.), Лексикон загального та порівняльного літературознавства (с. 155-156). Чернівці: Золоті литаври.

Ревзина, О.Г., \& Ревзин, И.И. (1971). Семиотический эксперимент на сцене. Труды по знаковым системам. Учёные записки Тартуского государственного университета (с. 232-254). Тарту.

Реутова, М. (2014). Форманти «театру абсурду» у драмі Юрія Косача «Кортез і Безталанна». Актуальні проблеми української літератури $і$ фольклору, 2122, 78-88.

Реферовская, Е.А. (2007). Коммуникативная структура текста в лексикограмматическом аспекте. Москва: Издательство ЛКИ.

Сапрыгина, Н.В. (2012). Психолингвистика художественного текста: коммуникация автора и читателя. Одесса: Астропринт. 
Деструкиія комунікативної прагматики в сучасних абсурдистських...

Шабат-Савка, С.Т. (2018). Психолінгвістичний вимір комунікативної інтенції: субстанція мовця та синтаксування. Psycholinguistics, 24 (2), 321-339. https:// doi.org/10.31470/2309-1797-2018-24-2-321-339

Шпильная, Н.Н. (2019). Невербализируемые высказывания как проявление полифонии языкового сознания при психозе. Вопросы психолингвистики, 2 (40), 150-156. https://doi.org/10.30982/2077-5911-2019-40-2-150-156

Azizmohammadi, F., \& Kohzadi, H. (2011). The Language of the Absurd Theatre in Pinter's Birthday Party. Journal of Basic and Applied Scientific Research, 1 (11), 2059-2062.

Bara, B.G. (2010). Cognitive Pragmatics: Mental Processes of Communication. Cambridge: MIT Press. https://doi.org/10.7551/mitpress/9780262014113.001.0001

Mihael, J., \& Overgaard, S. (2012). Interaction and social cognition: A comment on Auvray et al.'s perceptual crossing paradigm. New Ideas in Psychology, 30 (3), 296-299. https://doi.org/10.1016/j.newideapsych.2012.02.001

Rehman, H., \& Larik, A. (2017). Absurdity of language was a new form of drama for the people around 1950s in reference of Eugene Ionesco's play The Future is in Eggs. International Journal of Humanities and Social Science Invention, 6 (1), 72-79.

Simpson, P. (1998). Odd talk: studying discourses of incongruity. In J. Culpeper, M. Short \& P. Verdonk (Eds.), Exploring the Language of Drama: From Text to Context (pp. 34-53). London: Routledge.

Verschueren, J. (1999). Understanding Pragmatics. London and New York: Arnold.

Volden, J., Mulcahy, R., \& Holdgrafer, G. (1997). Pragmatic language disorder and perspective taking in autistic speakers. Applied PsychoLinguistics, 18 (2), 181198. https://doi.org/10.1017/S0142716400009966

\section{References}

Batsevych, F.S. (2012). Absurdnyi khudozhnii tekst u vymirakh linhvistychnoi prahmatyky [An absurd literary text in the dimensions of linguistic pragmatics]. Movoznavstvo - Linguistics, 1, 18-30 [in Ukrainian].

Bernar, B.H. (2013). Tematychna sitka anhlomovnoi dramy absurdu [Thematic grid of English-language drama of absurd]. Filolohichni traktaty - Philological treatises, 5 (2), 13-18 [in Ukrainian].

Vedmediev, V.M. (2018). Retseptsiia absurdnoho u filosofsko-antropolohichnomu dyskursi [Reception of absurd in philosophically-anthropological discource]. Extended abstract of Candidate's thesis. Kyiv [in Ukrainian].

Gamalej, N.S. (2001). Psiholingvisticheskoe issledovanie kategorii «osmyslennoe bessmyslennoe» kak konstanty konceptual'noj sistemy individa [Psychologicallylinguistic study of category «meaningful - meaningless» as constants of individual conceptual system]. Extended abstract of Candidate's thesis. Barnaul [in Russian].

Harashchenko, L. (2012). Poetyka «Teatru absurdu» v ukrainskii dramaturhii (na materiali piesy I. Kostetskoho «Spokusy ne sviatoho Antona») [Poetics of «Theatre of absurd» in Ukrainian dramaturgy (based on I. Kostetskoho's play «Temptations of not saint Anton»)]. Visnyk Cherkaskoho universytetu - Bulletin of Cherkasy University, 25, 81-97 [in Ukrainian]. 
Grajs, G.P. (1985). Logika i rechevoe obshhenie [Logic and speech communication]. In E.V. Paducheva (Ed.), Novoe v zarubezhnoj lingvistike. Lingvisticheskaja pragmatika - New in foreign linguistics. Linguistic pragmatics (pp. 217-237). Moscow: Progress [in Russian].

Zvegincev, V.A. (1973). Jazyk $i$ lingvisticheskaja teorija [Language and Linguistic Theory]. Moscow: Izdatel'stvo Mosc. un-ta [in Russian].

Ivleva, S.V. (2010). Lingvosemioticheskie harakteristiki komicheskogo absurda [Linguosemiotic characteristics of a comic absurdity]. Extended abstract of Candidate's thesis. Volgograd [in Russian].

Koliasa, O.V. (2016). Sutnist absurdu v postmodernistskomu khudozhnomu teksti [Essence of absurd in postmodern literary text]. Molodyi vchenyi - Young scientist, 3, 531-533 [in Ukrainian].

Kravchenko, O.V. (2010). Javlenija jazykovogo absurda v hudozhestvennyh tekstah [The phenomena of linguistic absurdity in literary texts]. Extended abstract of Candidate's thesis. Taganrog [in Russian].

Lazutkina, E.M. (2013). Rechevaja kultura megapolisa [Speech culture of a megalopolis]. Polifonija bolshogo goroda - 2 - Big city polyphony - 2 (pp. 5469). Moscow [in Russian].

Leontev, D.A. (2003). Psihologija smysla. Priroda, stroenie $i$ dinamika smyslovoj real'nosti [Psychology of sense. Nature, structure and dynamics of conceptual reality]. Moscow: Smysl [in Russian].

Lukjanova, V.S. (2002). Kommunikativnye neudachi v komedii absurda [Communicative failures in the absurd comedy]. Extended abstract of Candidate's thesis. Moscow [in Russian].

Myropolska, Ye.V. (2019). Estetychni zasady «filosofii absurdu» v mystetskykh praktykakh XX stolittia [Artistic principles of «phylosophy of absurd» in art practices of XX century]. Kyiv: Vydavnytstvo Lira-K [in Ukrainian].

Mukan, V.S. (2015). Poetyka absurdu v ukrainskii dramaturhii pershoi polovyny XX stolittia (na materiali tvoriv Mykoly Kulisha ta Ihoria Kostetskoho) [Poetics of absurd in Ukrainian dramaturgy of the first half of XX century (based on Mykola Kulish and Ihor Kostetskoho's works)]. Extended abstract of Candidate's thesis. Kyiv [in Ukrainian].

Popov, Yu. (2001). Drama absurdu [Drama of absurd]. A. Volkov (Ed.), Leksykon zahalnoho ta porivnialnoho literaturoznavstva - Lexicon of general and comparative linguistic studies (pp. 155-156). Chernivtsi: Zoloti lytavry [in Ukrainian].

Revzina, O.G., \& Revzin, I.I. (1971). Semioticheskij jeksperiment na scene. [Semiotic scene experiment]. Trudy po znakovym sistemam. Uchjonye zapiski Tartuskogo gosudarstvennogo universiteta - Works on sign systems. Scientific notes of Tartu State University (pp. 232-254). Tartu [in Russian].

Reutova, M. (2014). Formanty «teatru absurdu» u drami Yuriia Kosacha «Kortez i Beztalanna» [Formants of «theatre of absurd» in Yurii Kosach's drama «Kortez and Ill-fated»]. Aktualni problemy ukrainskoi literatury $i$ folkloru - Current problems of Ukrainian literature and folklore, 21-22, 78-88 [in Ukrainian].

Referovskaja, E.A. (2007). Kommunikativnaja struktura teksta $v$ leksikogrammaticheskom aspekte [The communicative structure of the text in the lexical and grammatical aspect]. Moscow: Izdatelstvo LKI [in Russian].

Saprygina, N.V. (2012). Psiholingvistika hudozhestvennogo teksta: kommunikacija avtora $i$ chitatelja [Psycholinguistics of literary work: communication between author and reader]. Odessa: Astroprint [in Russian]. 
Shabat-Savka, S.T. (2018). Psykholinhvistychnyi vymir komunikatyvnoi intentsii: substantsiia movtsia ta syntaksuvannia [Psycholinguistic Dimension of Communicative Intention: Speaker's Substance and Syntaxing]. Psykholinhvistyka - Psycholinguistics, 24 (2), 321-339. https://doi. org/10.31470/2309-1797-2018-24-2-321-339 [in Ukrainian].

Shpilnaja, N.N. (2019). Neverbaliziruemye vyskazyvanija kak projavlenie polifonii jazykovogo soznanija pri psihoze [Unverbalized statements as indication of polyphony of language perception during psychosis]. Voprosy psiholingvistiki Psycholinguistics issues, 2 (40), 150-156. https://doi.org/10.30982/2077-59112019-40-2-150-156 [in Russian].

Azizmohammadi, F., \& Kohzadi, H. (2011). The Language of the Absurd Theatre in Pinter's Birthday Party. Journal of Basic and Applied Scientific Research, 1 (11), 2059-2062.

Bara, B.G. (2010). Cognitive Pragmatics: Mental Processes of Communication. Cambridge: MIT Press. https://doi.org/10.7551/mitpress/9780262014113.001.0001

Mihael, J., \& Overgaard, S. (2012). Interaction and social cognition: A comment on Auvray et al.'s perceptual crossing paradigm. New Ideas in Psychology, 30 (3), 296-299. https://doi.org/10.1016/j.newideapsych.2012.02.001

Rehman, H., \& Larik, A. (2017). Absurdity of language was a new form of drama for the people around 1950s in reference of Eugene Ionesco's play The Future is in Eggs. International Journal of Humanities and Social Science Invention, 6 (1), $72-79$.

Simpson, P. (1998). Odd talk: studying discourses of incongruity. In J. Culpeper, M. Short \& P. Verdonk (Eds.), Exploring the Language of Drama: From Text to Context (pp. 34-53). London: Routledge.

Verschueren, J. (1999). Understanding Pragmatics. London and New York: Arnold.

Volden, J., Mulcahy, R., \& Holdgrafer, G. (1997). Pragmatic language disorder and perspective taking in autistic speakers. Applied PsychoLinguistics, 18 (2), 181198. https://doi.org/10.1017/S0142716400009966

\begin{abstract}
АНОТАЦІЯ
Метою в статmі $\epsilon$ характеристика механізмів руйнації прагматики в спілкуванні дійових осіб сучасних українських п'єс з ознаками театру абсурду. На фактичному матеріалі виділено структурні та контекстуальні механізми депрагматизації діалогічного мовлення. У драматургійному діалозі абсурдність пояснюємо цільовою настановою на донесення думки про алогічність та хаотичність реальності, безцільність людського буття.

Основними методами дослідження стали описовий, контекстуальноінтерпретаційний та пресупозиційний.

Результати дослідження. Одним з механізмів виникнення абсурду $\epsilon$ депрагматизація - цілеспрямоване ненормативне використання прагматичних ресурсів мови. у межах депрагматизації розрізняємо структурні й контекстуальні порушення. Структурні порушення характерні для абсурдистської драми, у якій репліки персонажів не мають іллокутивної й тематичної зв'язності. Іншим типом структурних порушень $\epsilon$ свідомі
\end{abstract}


порушення формальної структури мовних одиниць. Обмін ролями, за якого дійова особа перебирає на себе чужу комунікативну роль, $\epsilon$ прикладом контекстуальної депрагматизації. у межах контекстуальних порушень виділяємо групу когнітивних порушень, що грунтуються на недотриманні причиново-наслідкових $i$ логічних зв'язків. Контекстуальним різновидом депрагматизації вважаємо аномалії, основані на довільному виборі стилістичних засобів мови, що неузгоджені із загальними принципами стилістичного оформлення тексту.

Висновки. Структурні й контекстуальні комунікативні порушення драматурги використовують для активізації почуття абсурдності ситуації, змальованої у творі. Дійові особи драми абсурду спілкуються без комунікативної мети й урахування ситуативних потреб, наслідком чого стає актуалізація прагматичного потенціалу використаних мовних одиниць, фальсифікація осмисленого мовлення.

Ключові слова: прагматика, драматургійний дискурс, мовний абсурд, депрагматизація, структурні й контекстуальні порушення, «нересреренційні» висловлення.

\title{
Королёва Валерия \& Попова Ирина. Деструкция коммуникативной прагматики в современных драматургических абсурдистских текстах
}

\begin{abstract}
АННОТАЦИЯ
Целью статьи является характеристика механизмов разрушения прагматики в общении действующих лич современных украинских драматических произведений с признаками театра абсурда. На фактическом материале выделены структурные и контекстуальные механизмы депрагматизации диалогической речи. В драматургическом диалоге абсурдность вызвана целевой установкой на донесение мысли об алогичности и хаотичности окружающего мира, бесцельности человеческого бытия.
\end{abstract}

Основными методами исследования являются методы описательного, контекстуально-интерпретационного и пресуппозиционного анализов.

Результаты исследования. Одним из механизмов возникновения абсурда является депрагматизация - целенаправленное ненормативное использование прагматических ресурсов языка. В рамках депрагматизации различаем структурные и контекстуальные нарушения. Структурные нарушения являются характерными для абсурдистской драмы, в которой реплики персонажей не имеют иллокутивную и тематическую связность. Другим типом структурных нарушений являются сознательные нарушения формальной структуры языковых единиц. Обмен ролями, при котором действующее лицо берет на себя другую роль, считаем примером контекстуальной депрагматизации. В рамках контекстуальных нарушений выделяем группу прагмакогнитивных нарушений, которые основаны на несоблюдении причинно-следственных и логических связей. Контекстуальной 
Деструкиія комунікативної прагматики в сучасних абсурдистських...

разновидностью депрагматизации являются и аномалии, базированные на свободном выборе стилистических средств языка, несогласованных с общими принципами стилистического оформления текста.

Выводы. Структурные и контекстуальные коммуникативные нарушения драматурги используют для активизации чувства абсурдности ситуации, описанной в произведении. Действующие лица драмы абсурда общаются без коммуникативной цели и учета ситуативных потребностей, следствием этого стает актуализация прагматического потенциала использованных языковых единиц, фальсификация осмысленной речи.

Ключевые слова: прагматика, драматургический дискурс, языковой абсурд, депрагматизация, структурные и контекстуальные нарушения, «нерефреренционные» высказывания. 